\title{
Finite element modelling of composite castellated beam
}

\author{
Richard Frans ${ }^{1, *}$, Herman Parung ${ }^{2}$, Achmad Bakri Muhiddin ${ }^{2}$, and Rita Irmawaty ${ }^{2}$ \\ ${ }^{1}$ Doctoral Program, Hasanuddin University, Makassar, Indonesia \\ ${ }^{2}$ Department of Civil Engineering, Hasanuddin University, Makassar, Indonesia
}

\begin{abstract}
Nowadays, castellated beam becomes popular in building structural as beam members. This is due to several advantages of castellated beam such as increased depth without any additional mass, passing the underfloor service ducts without changing of story elevation. However, the presence of holes can develop various local effects such as local buckling, lateral torsional buckling caused by compression force at the flange section of the steel beam. Many studies have investigated the failure mechanism of castellated beam and one technique which can prevent the beam fall into local failure is the use of reinforced concrete slab as lateral support on castellated beam, so called composite castellated beam. Besides of preventing the local failure of castellated beam, the concrete slab can increase the plasticity moment of the composite castellated beam section which can deliver into increasing the ultimate load of the beam. The aim of this numerical studies of composite castellated beam on certain loading condition (monotonic quasi-static loading). ABAQUS was used for finite element modelling purpose and compared with the experimental test for checking the reliability of the model. The result shows that the ultimate load of the composite castellated beam reached 6.24 times than the ultimate load of the solid I beam and 1.2 times compared the composite beam.
\end{abstract}

\section{Introduction}

Castellation is one of technique for increasing the bending strength of steel beam and produce a new section property called castellated beam or also known as honey comb beam. Besides increasing the bending capacity of the beam, there are several advantages of using castellated beam such as reducing the total weight of the structures, passing the underfloor services (ducting and plumbing). But, in the other hand, castellated beam have disadvantages caused by holes present of the web section. Local buckling and Vierendeel mechanism sometimes took place. Therefore, composite beam becomes one of solution for avoiding the collapse mechanism. In composite beam, the concrete section will experience compression while tension will occur in the steel profiles. So, local buckling won't happen on the steel profiles caused by there is no compression force on the steel. Besides that, reinforced concrete slab can provide continuous lateral support to beam's flange which can

* Corresponding author: $\underline{\text { richardfrans.rf@gmail.com }}$ 
prevent the beam from lateral torsional buckling. The other advantage of using composite on the castellated beam is to increase the plastic moment of the steel beam which automatically increase the bending capacity of the beam. This paper considered a composite castellated beam as a comparison and validation with the composite beam (not castellated) which have been done [1].

\section{Castellated beam}

Castellated beams are those beams which has opening its web portion. Castellated beams are fabricated by cutting the web of hot rolled steel (HRS) I section into zig-zag pattern and thereafter rejoining it over one another [2]. Fig.1 shows the hexagonal castellated beam geometry section, where, $D_{o}$ is opening depth, $D$ is overall depth after castellation, $t_{w}$ is web thickness, $t_{f}$ is flange thickness, $b$ is flange width, $S$ is gross opening space, e is clearing opening space, $\alpha$ is opening angle.
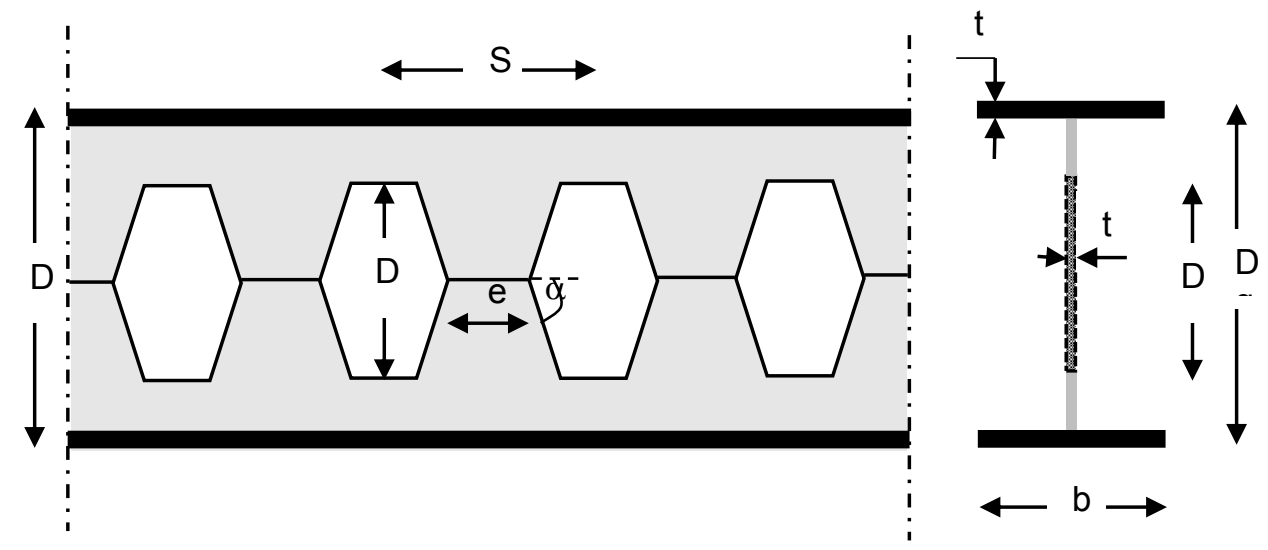

Fig. 1. Geometry of Castellated Beam.

Presence of the hole (opening) makes castellated beam susceptible to buckle. Two of the several failure mechanism which are common are Vierendeel mechanism and local buckling [3]. Vierendeel mechanism is mechanism that cause yield or buckling of the webpost in compression or shear when the other criteria is local buckling which can be occur in three ways [4]:

1. Buckling of the web-flange section (T-section) in compression due to global bending action. For unstiffened openings, this check is require for large opening in regions of high moment.

2. Buckling of the compressive strength.

3. Vertical instability of the sides of the web openings in high shear zones. Plated beams are more susceptible to this form of web instability.

\section{Composite beam}

Composite beam is a beam which has built with two different material (reinforced concrete slab and steel profile), both of them will work together against the external force. To ensure the composite behavior, the important factor must be noted that the bond between concrete and steel remain unbroken [5], hence the design of the shear connector must be well design. Reinforced concrete slab does not only increase the plastic capacity of the beam but also provide continuous lateral support at beam's flange to prevent lateral torsional buckling 
then the global instability problem is solved [6]. For local instability, if the composite beam is designed where the plastic neutral axis is lied on the reinforced concrete slab as shown on Fig.2., the local buckling of the steel beam can be neglected caused by there is zero compression force on the steel beam.

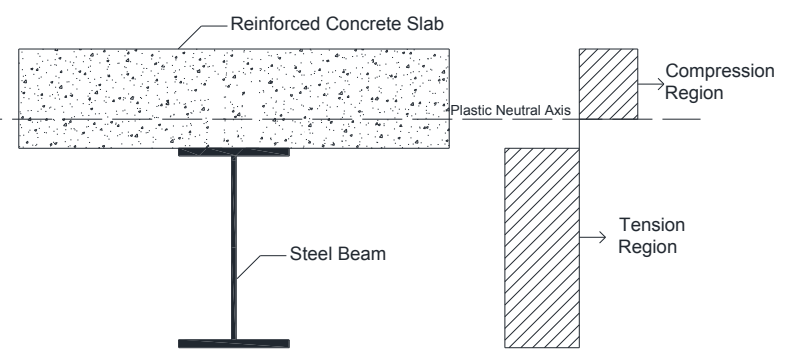

Fig. 2. Plastic Stress Distribution.

\section{Composite castellated beam}

Because of the advantage of composite beam describes above, the composite castellated beam was conducted in this paper. Fig.3. shows that the compression region lies on the concrete slab, while the tension region is in castellated beam, in this condition, reinforced concrete slab can prevent local buckling and Vierendeel mechanism so that the section can be developed until the plastic moment is reached. But, it must be noted that the shear connector had to design carefully so that composite action be guaranteed. Fig. 3 and Fig. 4 show the section of the composite castellated beam on the opening section and solid section respectively.

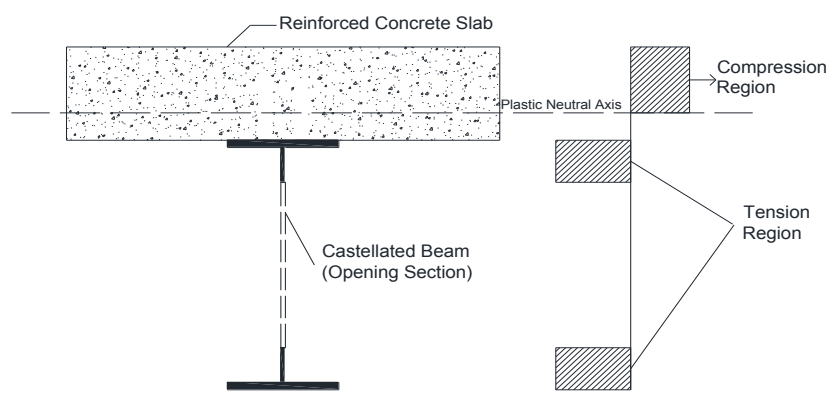

Fig. 3. Composite Castellated Beam (Opening Section).

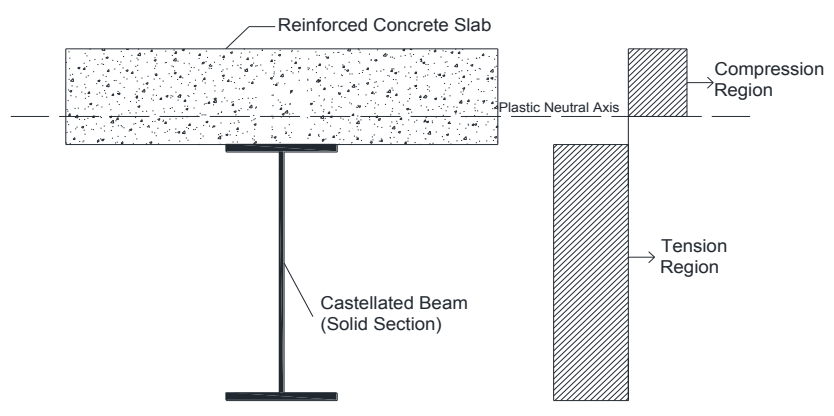

Fig. 4. Composite Castellated Beam (solid section). 


\section{Benchmark problem: composite steel beam}

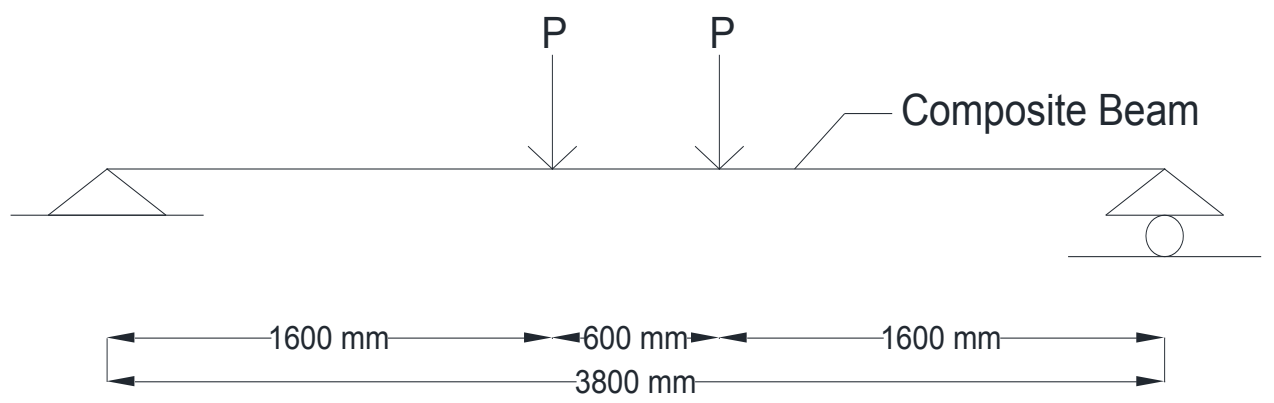

Fig. 5. Simply Supported Composite Beam.

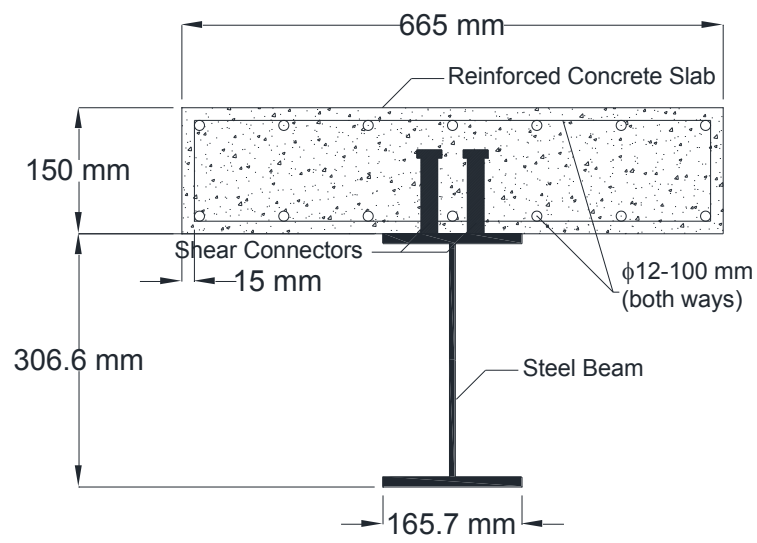

Fig. 6. Section Properties Composite Beam.

Before considered a composite castellated beam, a benchmark problem [1] was taken for test and validation purpose of the numerical modelling. The composite beam are shown on Fig. 5 and Fig. 6 respectively. The material properties and section properties can be seen on Table 1 and Table 2 respectively.

This composite steel beam was modelled using ABAQUS software (Finite Element Package). Eight-node brick elements with reduced integration (C3D8R) was picked for meshing purpose in [1]. But, for simplification of the model cause the cost of computation, the beam element was modelled using doubly curved shell elements 4-node with reduced integration (S4R) [7]. The composite behavior was provided using shear connectors (stud) and modelled using multi point constraint (MPC) option for full composite behavior [8]. This assumption used in this model (Fig. 7) has been validated with the numerical and experimental result in [1]. Monotonic loading (quasi-static) with two point bending has been used for loading condition. 
Table 1. Material properties of composite beam.

\begin{tabular}{|c|c|c|}
\hline \multicolumn{3}{|c|}{ Material Properties } \\
\hline & Concrete & Steel \\
\hline Density $\left(\mathrm{kg} / \mathrm{m}^{3}\right)$ & 2500 & 7850 \\
\hline Elastic modulus $(\mathrm{MPa})$ & 30000 & 210000 \\
\hline Poisson's ratio & 0.2 & 0.3 \\
\hline Compressive strength $(\mathrm{MPa})$ & 36 & \\
\hline & Hot-Rolled Beam Section & Reinforcement bars \\
\hline Yield Strength $(\mathrm{MPa})$ & 300 & 415 \\
\hline Ultimate strength $(\mathrm{MPa})$ & 420 & 550 \\
\hline
\end{tabular}

Table 2. Section properties of composite beam.

\begin{tabular}{|c|c|}
\hline \multicolumn{2}{|c|}{ Section Properties } \\
\hline \multicolumn{2}{|c|}{ Steel Beam } \\
\hline Cross section area $\left(\mathrm{mm}^{2}\right)$ & 5806 \\
\hline Total depth (mm) & 306.6 \\
\hline Flange width (mm) & 165.7 \\
\hline Flange thickness (mm) & 11.8 \\
\hline Web thickness (mm) & 6.7 \\
\hline Reinforced Concrete Slab \\
\hline Width (mm) & 665 \\
\hline Thickness (mm) & 150 \\
\hline Ratio of transverse reinforcement (\%) & 1.259 \\
\hline Ratio of longitudinal reinforcement (\%) & 1.259 \\
\hline
\end{tabular}

Reinforced Concrete Slab

(S4R) with Rebar Layers Option

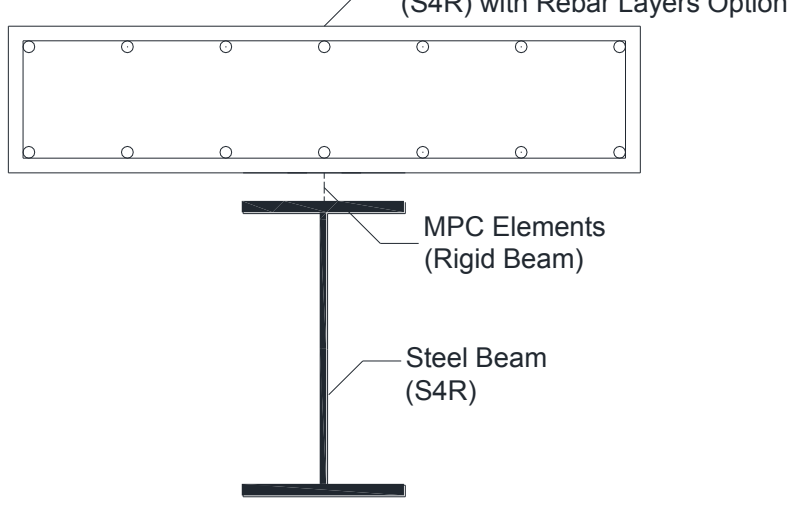

Fig. 7. Shell element assumption used based on [7]. 
Fig. 8 shows the load-deflection curve of the composite beam. The blue line and red line are experimental result and finite element modelling using FE-Solid (C3D8R) respectively which has been done by [5] while the green line is finite element modelling using FE-Shell (S4R). The yield load which obtained in the experimental result was about $360 \mathrm{kN}$, this is almost similar with the result of FE-Shell model which has $364,04 \mathrm{kN}$ of yield load. It also can be seen, the ultimate load (peak load) of the experimental result is around $550 \mathrm{kN}$ while the FE-Shell model is $557.96 \mathrm{kN}$. There is good agreement between the results of FE-shell model with the experimental result and FE-Solid model. So, FE-Shell model can be a good alternative solution for modelling the composite beam with lower cost of computation.

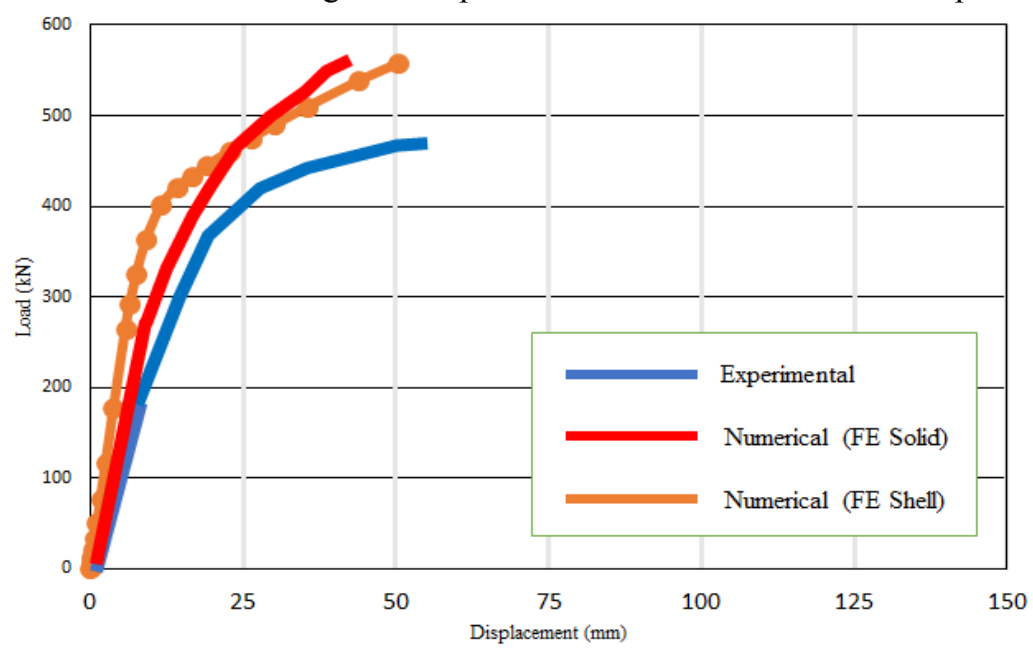

Fig. 8. Load-Deflection Curve for Composite Beam.

\section{Application of Composite Castellated Beam}

Composite castellated beam which considered were solid I beam with the same section properties as before but after castellation process. Properties of the castellated beam was used cutting pattern according to BS 5950-1:2000 which have an optimum properties for a castellated beam [9]. Fig. 9 shows the cutting pattern for steel beam, this pattern allows reducing of the secondary stress caused by the opening section [10].

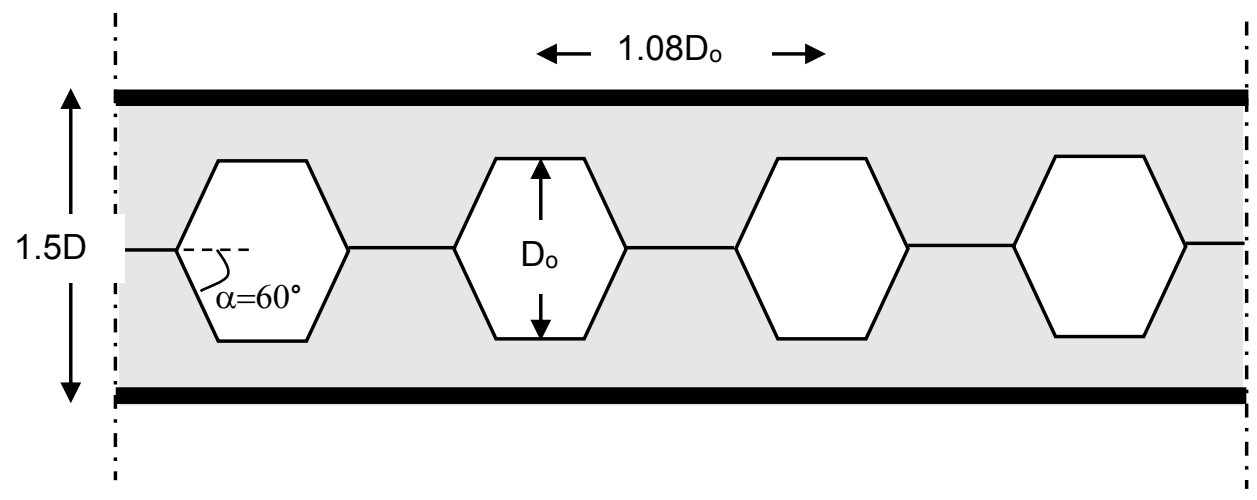

Fig. 9. Cutting pattern according to BS 5950-1:2000.

where, Do is opening height, and optimum angle $(\alpha)$ is $60^{\circ}$. 
Fig. 10 shows the steel beam before and after castellation process condition. Depth of the beam before castellation process was $306.6 \mathrm{~mm}$ and after castellation process the total height of the beam became $459.9 \mathrm{~mm}$. So, the depth increase about 1.5 times from the original beam (solid I beam). The cutting angle was taken $60^{\circ}$ with $331.128 \mathrm{~mm}$ of the opening space. Thickness of the reinforced concrete slab and the reinforcement bars are still same as before (Fig. 6). Beam's setup is also same as previous.

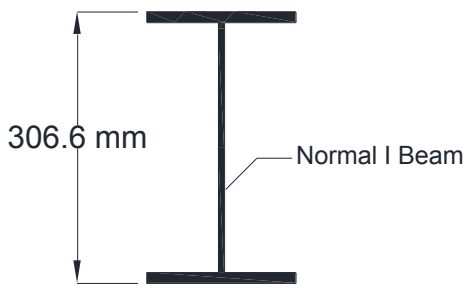

(a)

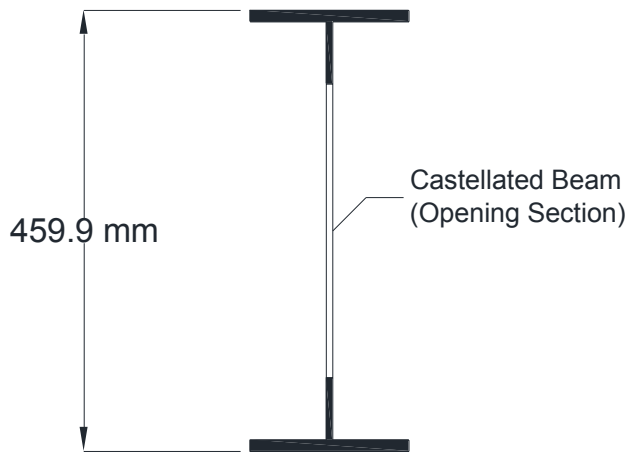

(b)

Fig. 10. (a) Normal I Beam, (b) Castellated Beam.

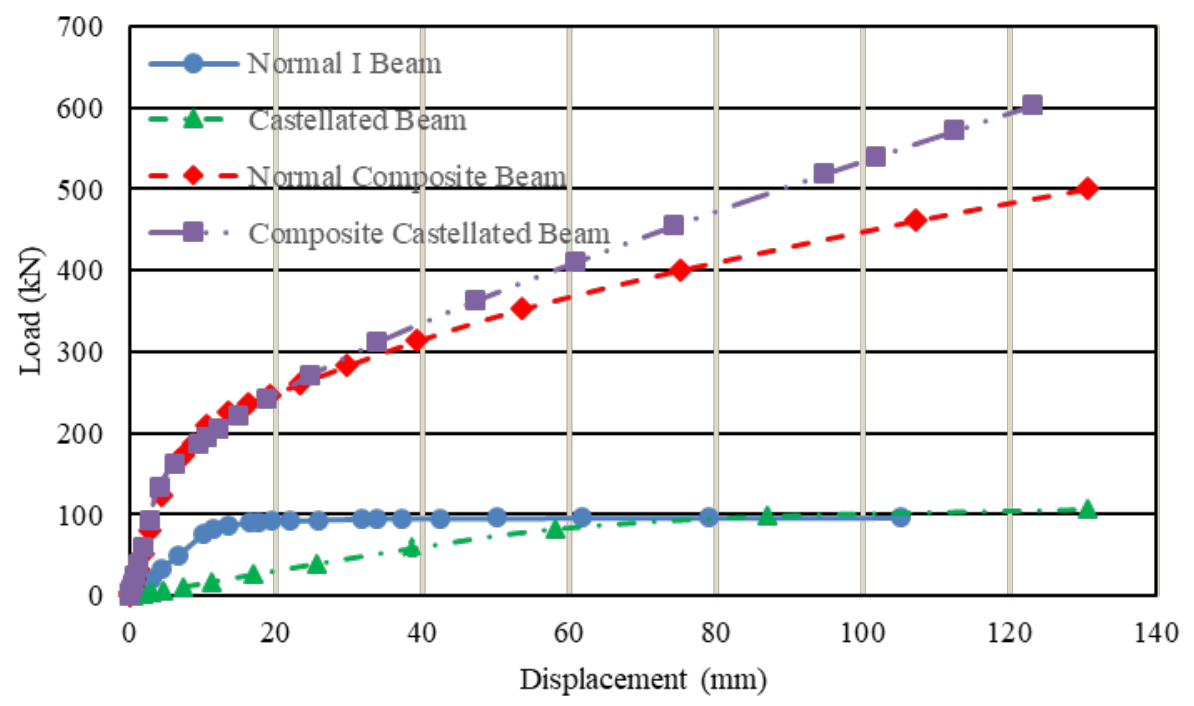

Fig. 11. Load-Displacement Curve for Various Type of Beam.

Fig. 11 shows the load-displacement curve of each type of beam. For comparison, the maximum displacement was taken $130 \mathrm{~mm}$. The blue line indicates the solid I beam while the green line indicates the castellated beam. It can be seen that solid I beam has a higher initial stiffness compared the castellated beam, but after yielding, the load capacity for solid I beam didn't increase significantly while castellated beam did, and at the last, the peak load for the solid I beam and castellated beam at the target displacement were $96.6021 \mathrm{kN}$ and $106.573 \mathrm{kN}$ respectively. 
For composite beam (solid I beam + reinforced concrete slab), the maximum load can be reached was $500.389 \mathrm{kN}$. This is almost five time higher than solid I beam. At the beginning, there is no difference between the composite beam and the composite castellated beam (the yield load is almost similar), but after around $270 \mathrm{kN}$, the composite castellated beam performed better than composite beam until the target displacement reached. The peak load of composite castellated beam was $603.146 \mathrm{kN}$. This value is 1.2 times from the composite beam and 6.24 times more than the capacity load of the solid I beam. Table 3 shows the comparison between the peak load which was reached for each type of beam. The peak load of the solid I beam became the reference peak load for comparing with the other type of the beam.

Table 3. Peak load.

\begin{tabular}{|c|c|c|}
\hline Type of Beam & Peak Load (kN) & Percentage (\%) \\
\hline Solid I Beam & 96.6021 & 100 \\
\hline Castellated Beam & 106.5730 & 110.3216 \\
\hline Composite Beam & 500.3890 & 517.9898 \\
\hline Composite Castellated Beam & 603.1460 & 624.3612 \\
\hline
\end{tabular}

\section{Conclusions}

Finite element which using shell element can be an alternative solution to make a simplification for the solid model. The composite beam which using S4R and MPC constraint (type rigid beam) was success to predict accurately the load-displacement curved compared with the numerical result which using solid element and the experimental result. The result shows good agreement between both of the model. The composite castellated beam shows the increasing of the capacity load significantly, this can be happened cause of the castellation process and the composite reaction between the steel profiles and the reinforced concrete slab. In this paper, the load capacity of the composite castellated beam was almost 6.24 times than solid I beam and 1.2 times compared by composite beam (solid I beam + reinforced concrete slab). Besides that, reinforced concrete slab can be a great lateral support for the beam to prevent lateral torsional buckling effect moreover failure mechanism such as local buckling and Vierendeel mechanism can be avoided cause of the neutral plastic axis is on the reinforced concrete slab. So, the steel beam can develop until the plastic moment reached.

\section{References}

1. A.N. Prakash, N.C.K. Anandavalli, C.K. Madheswaran, J. Rajasankar, N. Lakshmanan, "Three dimensional FE model of stud connected steel-concrete composite girders subjected to monotonical loading. International Journal of Mechanics and Applications", 1, 1-11 (2011)

2. A.M. Jamadar, P.D. Kumbhar, "Parametric study of castellated beam with circular and diamond shaped openings. International Research Journal of Engineering and Technology, India", 2015, 2, 715-722, (2015)

3. R. Frans, H. Parung, D. Sandy, S. Tonapa, "Numerical modelling of hexagonal castellated beam under monotonic loading”, 171, 781-788, Procedia Engineering (2017) 
4. D. Kerdal, D.A. Nethercott, "Failure modes for castellated beams", Journal of Construction Steel Research, 4, 295-315 (1984)

5. H. Parung, "Composite structures: behavior under earthquake loading", ISBN: 978602-0924-38-0, Masagena Press, Makassar (2017)

6. W. Dewobroto, "Struktur baja: perilaku, analisis \& desain" - AISC 2010 Civil Engineering Faculty, Tangerang (2016)

7. M. A. Gizejowski, W. Salah, "Failure modes of composite beams in the hogging moment region of continuous or semi-continuous systems. Proc. Local Seminar of the Polish Chapter of IASS, Warsaw", 114 - 136 (2007)

8. R.E.S. Ismail, A.S. Fahmy, N.M. Tawfik, "Finite element modelling of partially composite castellated beams. Communications on Applied Electronics (CAE)", 2, 6-22 (2015)

9. R. Frans, H. Parung, A.B. Muhiddin, R. Irmawaty, "Optimization of short-span hexagonal castellated beam using fast multi swarm optimization", International Seminar on Infrastructure Development (2016)

10. A. Aryatnie, "Studi Parametrik Castellated Beam terhadap Beban Gravitasi dengan Metode Blodgett dan Metode Darwin", Unpublished Thesis at Pelita Harapan University (2015) 